\title{
Jejak Historis Situs Eksplorasi Minyak Bajubang, Jambi
}

\author{
Azis Faturahman ${ }^{*}$ dan Aman \\ Program Studi Magister Pendidikan Sejarah, Fakultas Ilmu Sosial \\ Universitas Negeri Yogyakarta \\ Jl. Colombo No.1, Sleman, Daerah Istimewa Yogyakarta - Indonesia \\ *Alamat korespondensi: azisfaturahman750@gmail.com \\ DOI: https://doi.org/10.14710/jscl.v6i1.28314
}

Diterima/Received: 31 Januari 2020; Direvisi/ Revised: 1 Februari 2021; Disetujui/Accepted: 19 Juli 2021

\begin{abstract}
This article raises a discovery of one of the cities rich in potential oil resources in Indonesia, precisely at Bajubang, Jambi Province. This article is based on research conducted using historical methods including the collection of primary and secondary sources, including archival and literature studies, observations, as well as in-depth interviews. Since the discovery of the first oil in Bajubang Laut in 1916 by the Dutch through their oil company namely, Nederlandsch-Indische Aardolie Maatschappij (NLAM). The oil exploration in Bajubang raised a conflict between the Dutch enterprise and the United States enterprise called Standard Vacuum Petroleum Maatschappij (SVPM). Bajubang exploration site is one of the best and largest in the world that produces the best quality oil up until now. It is pure oil, contains good gas pressure, and low wax content. Bajubang had been ruled by three different eras, including NLAM which was under the Dutch government in 1920-1942, the Japanese colonial period from 1942-1945, and post-independence operated by the Republic of Indonesia Oil Company (Permiri) which has been changed to Pertamina. The glory of Bajubang oil exploration site occurred when Permiri produced avian turbine products as aircraft fuel. Bajubang exploration site also leaves historical traces such as hospitals, Dutch settlement, Japanese cave, Permiri oil refinery, mining equipments, churches, cinemas, schools, oil pipelines, and golf courses.
\end{abstract}

Keywords: Oil Exploration Site; Colonialization; Oil Production; Jambi.

\begin{abstract}
Abstrak
Artikel ini mengangkat penemuan tentang salah satu kota yang kaya akan potensi sumber daya minyak di Indonesia, yaitu di Bajubang, Provinsi Jambi. Artikel ini didasarkan pada penelitian yang dilakukan dengan menggunakan metode sejarah meliputi pengumpulan sumber primer dan sekunder yaitu studi arsip, observasi, dan wawancara mendalam terhadap narasumber terkait. Sejak penemuan sumur minyak pertama di Bajubang Laut pada 1916 oleh Belanda melalui perusahaan minyaknya yaitu Nederlandsch-Indische Aardolie Maatschappij (NIAM) menyebabkan konflik dengan perusahaan minyak Amerika Serikat bernama Standard Vacuum Petroleum Maatschappij(SVPM). Sumur minyak Bajubang merupakan salah satu sumur terbaik dan terbesar di dunia yang menghasilkan minyak berkualitas terbaik sampai sekarang, mengandung minyak murni dan tekanan gas yang juga bagus, serta kadar lilin yang kecil. Terdapat tiga pengelola sumber daya minyak di Bajubang yaitu NIAM pada 19201942, masa penjajahan Jepang 1942-1945, dan pasca-kemerdekaan oleh Perusahaan Minyak Republik Indonesia (Permiri) sampai saat ini bernama Pertamina. Puncak kejayaan kota minyak Bajubang terjadi pada era Permiri dengan produk avian turbin sebagai bahan bakar pesawat terbang. Situs kota minyak Bajubang juga meninggalkan jejak historis seperti rumah sakit, rumah Belanda, gua Jepang, kilang minyak Permiri, alat penambangan, gereja, bioskop, sekolah, pipa penyaluran minyak, dan lapangan golf.
\end{abstract}

Kata Kunci: Situs Eksplorasi Minyak; Kolonialisme; Produksi Minyak; Jambi.

\section{Pendahuluan}

Para pendatang Belanda pertama kali memasuki wilayah Nusantara pada 1596 dipimpin oleh Cornelis de Houtman (Ricklefs, 2001:70). Ketika itu Nusantara terkenal dengan limpahan rempah- rempah yang selama ini menjadi komoditi unggulan di Eropa. Pada 1602 Vereenigde Oostindische Compagnie (VOC) pun didirikan sebagai sebuah kongsi dagang. Eksplorasi Belanda di Nusantara kemudian berkembang dari yang sebelumnya di Pulau Jawa meluas hingga wilayah 
Sumatra dan Maluku. Jenis komoditi juga tidak terbatas hanya rempah, namun juga pertanian dan perkebunan seperti gula, teh, dan sebagainya (Ricklefs, 2001:320).

Minyak bumi diketahui telah terdeteksi di wilayah Nusantara melalui studi-studi yang dilakukan pemerintah Hindia Belanda di wilayah Sumatra, tepatnya di pesisir Aceh (Ooi, 1982: 1). Pada studi-studi tersebut, di Kepulauan Melayu termasuk Sumatra ditemukan sebuah bahan menakjubkan yang mudah terbakar di permukaan laut. Ketika itu, bahan tersebut belum didefinisikan sebagai minyak bumi. Baru dua abad kemudian istilah minyak bumi populer sebagai salah satu komoditi mentah penting sebagai sumber energi.

Provinsi Jambi adalah sebuah provinsi di Indonesia yang terletak di pesisir timur bagian tengah Pulau Sumatrra. Provinsi Jambi memiliki beberapa kabupaten dan kecamatan salah satunya adalah Kabupaten Batanghari dan kecamatan Bajubang. Bajubang merupakan kecamatan terluas di Kabupaten Batanghari yang luas wilayahnya adalah $1.203,51 \mathrm{~km}^{2}$ atau $20,73 \%$ total wilayah Kabupaten Batanghari. Kelurahan Bajubang merupakan ibukota dari kecamatan Bajubang (Rohati 2017: 3).

Perkembangan kota dipengaruhi oleh potensi sumber daya alam yang dimiliki oleh kota tersebut dalam mengelola dan memanfaatkan sumber daya alam, guna meningkatkan mutu kehidupan masyarakatnya (Kuncoro, 2003). Perkembangan pada wujud fisik kota merupakan manifestasi visual dan parsial yang dihasilkan dari interaksi komponen pembentuk yang saling mempengaruhi satu sama lainnya (Allain, 2004:254). Salah satu dari sumber daya alam yang dikelola dan dimanfaatkan suatu kota di antaranya minyak bumi. Pertumbuhan kota berdasar potensi sumber daya alam minyak bumi ini juga terjadi di Indonesia, salah satunya terdapat di Kecamatan Bajubang yang secara geografis berada di Kabupaten Batanghari, Jambi.

Penjajahan yang terjadi Indonesia khususnya penjajahan kolonial Belanda yang cukup lama membuat negeri ini mengalami pengaruh Barat dalam berbagai segi kehidupan termasuk kebudayaan. Hal itu antara lain dapat dilihat dari bentuk kota (Sumalyo, 1997: 3). Bajubang kota minyak merupakan salah satu jejak peninggalan pada masa pra-kemerdekaan RI.
Sementara daerah penghasil minyak bumi di Indonesia yang banyak dikenal publik selama ini seperti Brandan (Sumatra Utara), Cepu (Jawa Tengah), Riau, Plaju (Sumatra Selatan), Balikpapan (Kalimantan Timur), dan Tarakan (Kalimantan Utara).

Minyak yang dihasilkan di Jambi termasuk di Bajubang tidak disuling dan diolah, akan tetapi disaluran ke Plaju (Sumatra Selatan). Ini adalah salah satu penyebab Bajubang tidak dikenal sebagai daerah penghasil minyak. Pada 1935 dibangun pipa sepanjang $275 \mathrm{~km}$ menuju Plaju oleh NIAM sebagai pengelola dengan biaya mencapai 3,5 juta Gulden (Nieuwe Leidsche Courant, 10 Januari 1935). Dampak penyulingan minyak yang tidak berada di Bajubang menyebabkan produksi minya Bajubang masuk dalam catatan hasil ekspor Palembang oleh Belanda (Scholten, 2008:327). Pada 1916 Perusahaan Minyak Negara Belanda yang bernama NIAM masuk ke Jambi. NIAM menemukan Lapangan Jambi lewat pemboran pertama Sumur Bajubang-1 (BJG-01) pada 1922.

Belanda pertama kali melakukan pengeboran di daerah Bungin Batu, sebuah nama yang diberikan oleh Belanda yang berarti Pasir Kasar. Tempat pengeboran yang ada di Bajubang Laut kemudian dilanjutkan pada 1916 di daerah Sridadi dan Malapari. Ditemukan bahwa kualitas minyak bumi di Sridadi dan Malapari berkualitas baik, akan tetapi terdapat kandungan gas beracun sehingga akhirnya ditutup. Kemudian pengeboran yang dilakukan di daerah Pasar Muara Tembesi pada 1920 yang dilanjutkan di daerah Betung, Bajubang serta Jambi pada 1918-1928. Kegiatan itu ternyata menghasilkan minyak berkualitas terbaik di dunia, minyak murni (crude oil) dengan tekanan kadar gas yang baik, serta kadar lilin yang rendah.

Pada 1928 di daerah Bajubang, NIAM juga berhasil mendapatkan konsensus pengeboran sumur minyak Bajubang yang diketahui sebagai sumur terbaik dan terbesar di dunia. Oleh sebab itu, Bajubang dijadikan pusat perkantoran oleh NIAM dan disebut sebagai Kota Minyak pada saat itu. Namun sejak 2011, cadangan minyak yang terus menerus mengalami penurunan membuat Bajubang tampak sepi karena ditinggal pindah oleh pegawai dan keluarganya ke Kenali Asam Atas, Kecamatan Kota Baru, yang dekat dengan Kota Jambi (Hasibuan, 2017:141). 
Puncak kejayaan minyak terjadi ketika NIAM berhasil memroduksi 30 ribu barel minyak per hari. Jejak Jambi bahkan dikenal sebagai produsen utama avian turbin, bahan bakar pesawat terbang pada masa Revolusi. NIAM sukses membangun peradaban sekaligus kota modern pertama di Jambi yang berada di Bajubang dengan dilengkapi fasilitas mentereng. Sumur minyak yang dimiliki Pertamina di Bajubang saat ini merupakan lokasi perminyakan yang tua di Provinsi Jambi dan masih berproduksi dengan baik. Luas areal Pertamina Bajubang seluas 1.327 ha dari 5.600 ha luas wilayah Kelurahan Bajubang yang terletak di Provinsi Jambi dan Sumatra Selatan (Wawancara dengan Suwastio, 10 November 2018).

Keberadaan Bajubang juga dikenal sebagai kota kolonial. Sebagaimana kota kolonial di Jawa, kajian mengenai kota kolonial misalnya bisa dilihat dalam tulisan Karyono dan Suryo (2002) mengenai bagaimana perkembangan kota Salatiga sebagai kota kolonial. Dalam kajian tersebut dibahas tentang berbagai aspek perkembangan kota seperti bidang pendidikan, transportasi, kesehatan, agama, sistem perekonomian, dan kebudayaan. Hal tersebut ditandai dengan adanya perkantoran, benteng, rumah-rumah, rumah ibadah, dan lain-lain (Makkelo, 2017:87).

Sama seperti tulisan Karyono dan Djoko Suryo yang membahas aspek perkembangan kota Salatiga, Bajubang juga memiliki rumah sakit sebagai sarana kesehatan, gereja Oikumene (agama), minyak sebagai sumber perekonomian, perkantoran, rumah-rumah bos NIAM, lapangan golf sebagai sarana hiburan, dan sebagainya.

Kajian ini penting karena kajian sejarah Jambi khususnya mengenai kota minyak Bajubang belum mendapat perhatian yang serius dibandingkan dengan daerah lainnya di Sumatra seperti Aceh, Minangkabau (Sumatra Barat), Sumatra Selatan (Plaju), Bangka Belitung, Sumatra Timur, Riau, dan Kepulauan Riau. Hingga saat ini, hanya ada dua kajian yang membahas aktivitas penambagan minyak di Jambi secara mendalam. Atas dasar itu, perkembangan Bajubang sebagai daerah pengeboran minyak yang penting sejak masa kolonial perlu diketengahkan, termasuk dinamika yang terjadi di dalamnya sejak masa kolonial hingga pasca-kemerdekaan. Kajian ini juga memberikan bukti-bukti peninggalan sejarah sehingga memperkuat argumentasi Bajubang menjadi salah satu situs penting dalam sejarah eksplorasi minyak di Nusantara.

\section{Metode}

Artikel ini disusun berdasar pada penelitian dengan metode sejarah. Metode ini dijabarkan ke dalam serangkaian kegiatan, yaitu mengumpulkan dan memverifikasi sumber, menginterpretasi fakta, dan kemudian merekonstruksinya menjadi kisah sejarah (Black dan McRaild, 2007).

Sumber data dalam kajian ini menggunakan interview (wawancara) langsung secara mendalam melalui pertanyaan terbuka (terarah) dengan narasumber yang mengetahui sejarah situs Kota Minyak di Bajubang dari masa kolonial Belanda sampai pasca-kemerdekaan. Kemudian sumber lisan yang berupa wawancara dengan para tokoh terkait (pelaku sejarah, tokoh masyarakat, dan masyarakat setempat) juga telah digali untuk menjawab permasalahan.

Sementara itu, kegiatan lapangan terdiri atas tiga tahap. Tahap pertama, pengumpulan data di lapangan dalam rangka memperdalam analisis yang berkaitan dengan sejarah situs kota minyak di Bajubang Provinsi Jambi. Tahap kedua, pengolahan data/analisis data hasil temuan di lapangan yang diperoleh baik data lapangan maupun kajian arsip dan kepustakaan.

Sumber-sumber yang telah dikumpulkan selanjutnya dikritik sehingga diperoleh fakta-fakta sejarah yang kredibel. Fakta-fakta sejarah itu kemudian diinterpretasi berdasar pada prinsip kronologis dan hubungan sebab-akibat, untuk selanjutnya dikontruksi menjadi kisah sejarah (history as written).

\section{Perkembangan Bajubang sebagai Kota Minyak di Jambi}

Secara hitoris, asal mula nama Bajubang berdasar pada legenda masyarakat setempat. Awalnya di masa pra-kemerdekaan RI, ada para pekerja pencari minyak dan gas seperti orang dari Amerika, Prancis, Belanda dan orang Indonesia sendiri yang saat itu disebut dengan Rombongan Siolo, mereka melakukan perjalanan melintasi hutan belantara untuk mencari lokasi minyak, di dalam perjalanan 
mereka bertemu dengan rombongan lain yang mengenakan pakaian serba merah yang dalam Bahasa Jawa disebut dengan abang (Rohati 2017:4).

Setiap Rombongan Siolo berhenti dan beristirahat ataupun bermalam, rombongan berbaju merah tersebut selalu mengikuti setiap gerak gerik Siolo, sehingga Rombongan Siolo memutuskan untuk mendahului rombongan berbaju merah itu. Adapun berbagai peralatan berat ditinggalkan untuk mempermudah pengejaran, namun semakin keras mereka berusaha untuk mendahuluinya, usaha Rombongan Siolo selalu mengalami kegagalan, bahkan seolah-olah rombongan Baju Abang menghilang tanpa jejak, tempat mereka menghilang tersebut dinamai Bajubang. Nama Bajubang berasal dari kata Baju dan Abang. (Wawancara dengan Sumbada, 18 November 2018).

Sementara itu, penetrasi kolonial di Jambi semakin kuat pada 1877-1879 yang ditandai dengan pengiriman ekspedisi yang terkenal dengan sebutan Midden Sumatra Expeditie. Ekspedisi tersebut bertujuan untuk mengumpulkan informasi tentang kondisi geografis dan masyarakat Jambi (Kanumoyoso, 2018).

Sejarah suatu kota dipandang begitu penting, bukan saja menjadi memorial atau sesuatu yang membanggakan saja, tetapi menyiratkan identitas yang membedakan dengan kota lain (Susanto, 2011:47). Proses pembentukan kota dengan pemukiman terjadi karena pemusatan aktivitas manusia untuk mendapatkan akses sumber daya tertentu dan melakukan proses mukim. Fenomena di perkotaan meliputi pembentukan pola permukiman yang dihubungkan dengan kondisi morfologi yakni yang tercermin pada penggunaan lahan, pola-pola jalan, dan tipe-tipe bangunan (Yunus, 2006).

Ekspresi keruangan bentuk permukiman kota minyak Bajubang dapat dikategorikan sebagai bentuk fan shaped city (kota kipas/kota kompak). Bentuk keruangan berupa lingkaran, bentuk kipas ini disebabkan oleh adanya hambatan-hambatan yang menghambat pertumbuhan kota pada araharah tersebut. Hambatan tersebut yaitu luasnya hutan belantara, rawa-rawa, dan perkebunan kelapa sawit.
Pola pemukiman di Bajubang membentuk pola pemukiman terpusat (dapat dilihat pada Gambar 1) yaitu mengelompok membentuk unitunit kecil dan menyebar (Setianto dan Murjainah, 2019:62). Pada daerah pertambangan seperti Bajubang, pemukiman memusat mendekati lokasi pertambangan. Penduduk yang tinggal di pemukiman terpusat biasanya masih memiliki hubungan kekerabatan dan hubungan dalam pekerjaan.

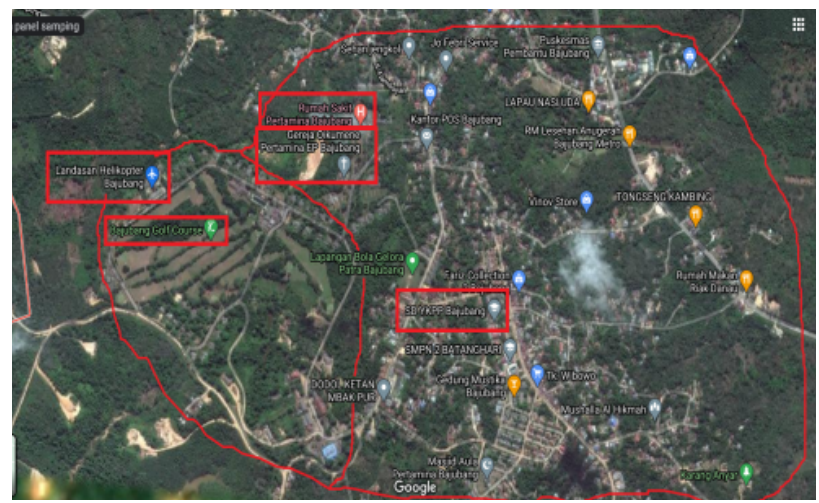

Gambar 1. Morfologi dan Pola Pemukiman di Kota Minyak Bajubang.

Pola pemukiman ini sengaja dibuat untuk mempermudah komunikasi antar keluarga atau antar teman kerja. Pemukiman terpusat biasanya juga dibangun mengelompok berdasarkan pusat pertumbuhan yang ada di daerah tersebut terutama pusat pertumbuhan fasilitas umum seperti rumah sakit, sekolah, pasar, pusat perkantoran, dan fasilitas umum lainnya.

Perusahaan minyak di Jambi telah direncanakan oleh kolonial Belanda sejak 1912 dengan membangun enam perusahaan yang mengambil bagian. Perusahaan NIAM mendirikan perusahaan di Jambi pada 1921. Pada 1916, NIAM masuk ke Jambi, tepatnya di Simpang Tiga Muara Bulian (Simpang Empat Tapa Malenggang, sekarang). Di daerah itu terdapat pelabuhan kapal Belanda dan pelabuhan kapal minyak, pelabuhan bersejarah tersebut saat ini masih ada yakni dijadikan Kantor ASDP Batang Hari (Poesponegoro, dkk., 2007:201). Penemuan sumur minyak yang berada di Lapangan Jambi pada 1922 diketahui mengandung hidrokarbon, khususnya pada struktur Betung dan Bajubang. Hal itu juga ditemukan di Tempino pada 1928, di Kenali Asam pada 1929, kemudian di Sungai Lilin Sumatera Selatan pada 1934, selanjutnya di Setiti 
pada 1936. Pada 1938, 1971, dan 1985 ditemukan juga sumur minyak masing-masing di Meruo Senami, Sengeti, dan hidrokarbon di Ketaling bagian Timur (Rohati 2017:5).

Kegiatan pengeboran dilakukan pertama kali oleh NIAM di daerah Bungin Batu, sebuah nama yang diberikan oleh Belanda yang berarti pasir kasar, tempat pengeboran berada di Bajubang Laut. Kemudian pengeboran dilanjutkan pada 1916 di daerah Sridadi dan Malapari.

Penemuan sumur minyak dan aktivitas pengeboran tersebut menjadi sumber konflik antara Belanda dan Amerika Serikat yang usai Perang Dunia I, melalui sekutunya, yaitu Prancis dan Inggris, telah secara agresif melakukan eksplorasi ke ladang minyak Timur Tengah. Amerika Serikat berharap perusahaan minyaknya dapat mengelola eksplorasi minyak di Jambi. Sengketa antara Belanda dan Amerika Serikat tersebut terekam dalam berita koran yang berjudul "Djambi's Oil that Has Troubled International Waters." ( The New York Times, 10 Juli 1920).

Persaingan itu terjadi beerapa tahun dan tidak kunjung selesai. Akhirnya setelah perdebatan sengit, sebuah draf berupa Rancangan Undangundang tanggal 22 November 1920 telah diterbitkan. Pada draft itu disampaikan bahwa dalam kontraknya kemudian menyertakan fakta bahwa pengelolaan minyak di Jambi termasuk Bajubang dipercayakan kepada NIAM (Moor, 1928:154).

Hambatan awal yang dihadapi pada kegiatan pengoboran sumur minyak di Jambi, khususnya pada daerah Bungin Batu, memang menghasilkan produk minyak yang bagus, akan tetapi terdapat kadungan gas beracun sehingga akhirnya ditutup. Kemudian pengeboran dilakukan di daerah Pasar Muara Tembesi pada 1920, dan kemudian di Bajubang pada 1928. Baru di Bajubang (Bjb) ditemukan sumur terbaik dan terbesar di dunia, pada situs nomor 01, 02, di daerah Betung, Bajubang, Jambi. Produk minyak Bajubang menghasilkan minyak murni berkualitas terbaik dan mengandung gas yang rendah, serta kadar lilin yang rendah.

Perkembangan selanjutnya, setelah kalah dalam perdebatan mengenai minyak Jambi pada 1920, ada perusahaan Amerika Serikat yakni Asam Merah (orang Amerika Serikat) ${ }^{3}$ atau disebut juga
SVPM dan masuk dua perusahaan Amerika baru yaitu Standard Oil of New Jersey dan Standard Oil of New York. Kedua perusahaan itu bekerja sama dengan pribumi melakukan kontrak pengeboran di lokasi kontrak perawatan sumur di Bajubang, Tempino, Kenali Asam, kemudian berlanjut sampai berubah nama menjadi Joint Operasional Body (JOB) termasuk perusahan tambang lainnya yang beroperasi sampai sekarang (Wawancara dengan Sukarman, 19 November 2018).

Pada saat masa kekuasaan Jepang, didirikan tempat latihan tenaga kerja yakni pendidikan minyak di Air Hitam, Sungai Gelam, dan di Kenali Asam serta dilaksanakan kursus pengeboran, geologi perminyakan dan pemeliharaan sumur, sampai pendidikan berlanjut di Prabu Mulih, Sumatera Selatan. Karena memiliki berbagai sumur minyak, Bajubang menjadi pusat eksplorasi minyak yang ditandai dengan pengembangan kompleks Pertamina.

Sementara itu, pada masa pendudukan Jepang, sumber daya alam terutama minyak bumi di Bajubang dikuasai untuk mendukung industri pertahanan Jepang. Di Bajubang, Pemerintah Jepang menguasai aset yang sebelumnya dikuasai Belanda. Jepang juga mendapatkan data terkait sumber minyak yang belum dieksplorasi melalui dokumen peninggalan Belanda. Pada 1944, Jepang menemukan lapangan Minas, Riau, yang merupakan ladang minyak terbesar di Asia Tenggara (Dharmasaputra, 2015).

Pemerintah Militer Jepang meninggalkan berbagai gua dan galian, kolam, dan tempat pembakaran. Ketika menguasai Bajubang, Jepang sengaja membangun gua sepanjang $1 \mathrm{~km}$ dengan dinding rangka baja untuk tempat pembunuhan massal. Tempat itu digunakan untuk membunuh satu persatu orang yang dianggap melawan dengan cara dipenggal atau disetrum listrik. Pendapat lain menyebutkan bahwa lubang atau terowongan sepanjang $1 \mathrm{~km}$ dimanfaatkan sebagai benteng pertahanan oleh tentara Jepang untuk menghubungkan markas dengan pintu keluar. Namun gua Jepang ini sekarang tidak terawat seperti di Padang (Wawancara dengan Sukarna, 20 November 2018).

Setelah Jepang kalah dalam perang Asia Pasifik, Belanda (NICA) $)^{5}$ bertekad ingin menjajah kembali bangsa Indonesia setelah merdeka yakni 
dengan melakukan pelanggaran setiap perjanjian internasional Indonesia-Belanda yaitu Perjanjian Linggarjati dan Renville. Taktik dan politik keji Belanda mampu merebut beberapa lokasi tambang minyak. Selanjutnya terjadi pertempuran para pejuang dan rakyat melawan Belanda yang terus berlangsung sampai perang pada agresi militer Belanda. Namun, pihak Belanda dan pejuang di Bajubang mengadakan perlawanan melalui taktik strategi militer yaitu perang gerilya serta politik internasional dan diplomasi.

Pada Agresi Militer Belanda I dan II, situs minyak di Jambi berperan sangat penting untuk penyulingan minyak pesawat udara, pembuatan berbagai macam bentuk senjata di bengkel, dan sebagai pertahanan yang siap memblokade serangan Belanda. Pasukan Belanda mengincar Bajubang karena mempunyai objek vital dalam hal persediaan bahan bakar pesawat, pasukan tentara Belanda dengan parasut mendarat di Perkuburan Bajubang (di TPU Kampung Baru sekarang) sehingga menimbulkan pertempuran di Bajubang (Dinas Kebudayaan dan Pariwisata Provinsi Jambi 1990:19).

Menurut Rohati (2017:7), pejuang rakyat Jambi bergerilya menghadapi musuh yang memiliki peralatan modern dan canggih serta tantangan bahwa beberapa lokasi tambang minyak dan hasil bumi telah dibumihanguskan. Pada saat Agresi Militer kedua, Belanda (NICA) melakukan serangan ke seluruh kota, desa, dan ibu kota negara Yogyakarta. Begitu juga dengan ibu kota Keresidenan Djambi (Kota Jambi) tidak luput dari sasaran serangan dahsyat dengan kekuatan penuh, termasuk daerah Bajubang. Selanjutnya pada pukul 29 Desember 1948, pukul 14.30, dalam waktu bersamaan, Bajubang, Kenali Asam, dan Tempino diserang dengan pesawat udara serta para Trup Belanda (Rohati 2017:5).

Upaya perlawanan terus dilakukan oleh para pejuang untuk mempertahankan Kecamatan Bajubang, hingga pada akhirnya Bajubang terkenang pada sebuah Tugu Pejuangan Rakyat Bajubang yang dibangun oleh pemerintah dan berlokasi di RT 14. Bajubang merupakan salah satu tempat ladang minyak yang ada di Provinsi Jambi termasuk Tempino, Kenali Asam, Sengeti, Ladang Peris, Pompa Air, dan Petaling yang sampai sekarang masih ada dan masih beroperasi. Borboran (pumping) ${ }^{6}$ masih ada di beberapa tempat.
Untuk menggambarkan perjuangan masyarakat Bajubang melawan pemerintah Belanda, maka dibuat suatu relief Monumen Tugu Juang Bajubang agar masyarakat Bajubang tidak pernah melupakan perjuangan dalam melawan penjajah dan mempertahankan kemerdekaan.

Bajubang tampak begitu ramai karena aktivitas perkantoran Pertamina dengan sarana dan prasarana yang lengkap. Sarana dan prasarana tersebut mulai dari sarana pendidikan, kesehatan, olahraga, rekreasi, dan hiburan tersedia di Bajubang. Di Bajubang sudah ada rumah sakit (RS) Pertamina yang selalu buka 24 jam, bahkan pasien berasal dari berbagai daerah lain, termasuk seperti Sumatera Selatan dan Riau. Sarananya tersedia lengkap, mulai dari bangunan gedung, sal, kamar, dan paramedis (Wawancara dengan Zainal Abidin, 09 Juli 2018).

Sarana pendidikan berupa sekolah sudah ada di Bajubang sejak masa penjajah Belanda. Pada saat dikuasai oleh Pertamina, seluruh sekolah, dari mulai TK sampai SMA, di Bajubang berada di bawah naungan Pertamina. Bangunan sekolah juga dibangun oleh pemerintah dan berstatus negeri serta satu TK yang berada di bawah naungan Yayasan Kesejahteraan Pegawai Pertamina (YKPP). Keberadaan sarana olahraga mulai dari lapangan voli, sepak bola, badminton, lapangan tenis, tenis meja, kolam renang, dan bahkan lapangan golf tersedia dan dapat dimanfaatkan oleh masyarakat dari berbagai kalangan termasuk dari luar Provinsi Jambi.

Sarana rekreasi Bajubang dahulu memanfaatkan lokasi Pramuka untuk kegiatan perkemahan dan camping serta juga memiliki bioskop yang aktif untuk sarana hiburan masyarakat. Sekarang sarana itu ada namun karena Pertamina kantornya pindah tahun 2011 ke Kenali Asam, Jambi (Sekarang Kelurahan Kenali Asam Atas Kecamatan kota Baru) maka sarana yang ada tidak lagi dimanfaatkan dan terbengkalai (Wawancara dengan Zainal Abidin, 09 Juli 2018).

Kondisi di Bajubang sekarang pihak pemerintah melalui Kelurahan Bajubang terus melayangkan surat kepada pihak Pertamina pusat di Jakarta agar jalan milik Pertamina yang dimanfaatkan masyarakat sekitar dalam kondisi rusak berat dapat diserahkan/dihibahkan kepada Pemda Batanghari dengan harapan dapat di aspal oleh Pemda menggunakan dana APBD karena 
syaratnya demikian. Kondisi ini membuat hilangnya rasa kepercayaan masyarakat terhadap Pertamina, karena masyarakat tidak dapat menikmati hasil pembangunan infrastruktur jalan seperti layaknya masyarakat lain di Kabupaten Batanghari (Rohati 2017:32).

Terdapat berbagai peralatan pertambangan minyak yang telah rusak di sana. Peralatan tersebut merupakan peralatan untuk mengangkat minyak ke atas. Namun, peralatan tersebut kondisinya sekarang sudah rusak dan tidak bisa dipakai lagi. Selain itu, dari hasil pengamatan terdapat gedung yang rusak berat, sementara masyarakat tidak boleh memanfaatkan gedung tersebut tanpa seizin pihak Pertamina, pegawai sudah banyak berkurang, angka pengangguran meningkat akibat tidak berfungsinya Pertamina Bajubang secara maksimal.

Kabar mengenai fasilitas komplek Pertamina akan dihuni kembali oleh para pegawai Pertamina dan janji itu selalu dihembuskan oleh pihak Pertamina. Masyarakat menyambut gembira dengan rencana yang dimaksud, namun hingga saat ini janji tinggal janji komplek pertamina kosong tidak berpenghuni, terbengkalai, dan kesannya seram bahkan ada kemungkinan dipakai untuk kegiatan maksiat oleh oknum yang tidak bertanggung jawab.

\section{Situs Peninggalan Kolonial Belanda di Kota Minyak Bajubang Provinsi Jambi}

Dalam Kamus Besar Bahasa Indonesia (KBBI), situs sejarah merupakan daerah dimana ditemukan benda-benda purbakala (Tim Penyusun Kamus Pusat Bahasa, 2007:1078) Situs sejarah memiliki berbagai kegunaan. Selain sebagai penelitian arkeologis, situs sejarah dapat juga dimanfaatkan sebagai sumber belajar siswa dimana siswa bisa berlatih menganalisa peristiwa sejarah berdasarkan bukti sejarah yang berupa situs sejarah tersebut. Sedangkan Menurut William Haviland (dalam Warsito 2012:25) mengatakan bahwa situs merupakan tempat-tempat dimana ditemukan peninggalan-peninggalan arkeologi di kediaman manusia pada zaman dahulu. Dapat disimpulkan bahwa situs merupakan tempat dimana terdapat informasi tentang peninggalan-peninggalan bersejarah. Adapun situs-situs di Bajubang adalah sebagai berikut.

\section{Rumah peninggalan Belanda}

Rumah merupakan salah satu bangunan yang paling banyak dari peninggalan bangsa Belanda di Indonesia diantaranya seperti yang terdapat di Bajubang. Rumah ini dahulunya adalah rumah orang Belanda yang dibangun oleh bos-bos pegawai minyak NIAM pada 1922 . Namun saat ini pemiliknya telah pindah sehingga ditempati oleh orang-orang sekitar dan sudah banyak renovasi dari bentuk aslinya.

Eksploitasi minyak di Jambi termasuk Bajubang menampung jumlah pekerja yang cukup besar. Tahun 1925 jumlah pekerja yang bekerja dalam eksplorasi minyak sebanyak 658 pekerja lokal, sementara tenaga kerja orang Eropa sebanyak 31 orang yang terdiri dari ahli geologi, admin administrasi, pegawai teknis, pengelola lokasi, tenaga bor, asisten operator lokasi, pengawas bengkel, pengawas, dan sopir untuk jalur pipa (De Sumatra Post, 28 Oktober 1926).

Pada 1937, terdapat 49 pekerja level senior yang diduduki oleh orang Belanda, tiga diantaranya bukan asal Belanda. Banyak juga masyarakat lokal yang bekerja dengan NIAM. Pekerjaan tingkat level bawah diperuntukkan bagi masyarakat asli, ini adalah komitmen dari NIAM itu sendiri (Het Nieuws Van den Hag, 13 September 1938). Tahun 1938 terjadi peningkatan jumlah personil Eropa terutama disebabkan oleh ukuran yang lebih besar dari perusahaan pengeboran dan ekstraksi pada tahun 1938 (Jaarverslag NVNLAM, 1938: 8).

Peninggalan rumah (pada Gambar 2) di Bajubang dapat terlihat dari bentuk bangunan yang masih mencirikan arsitektur khas kolonial. Bangunan yang dibangun pada masa kolonial ini rata-rata memiliki bentuk bangunan yang simetris, bertembok tebal dengan langit-langit yang tinggi. Bagian depan terdapat pilar-pilar dengan tata ruang terbuka, beratap perisai dengan beranda luas, pintu dan jendela berukuran besar, dan didominasi warna putih (Wawancara dengan Rusman, 09 Juli 2018). 


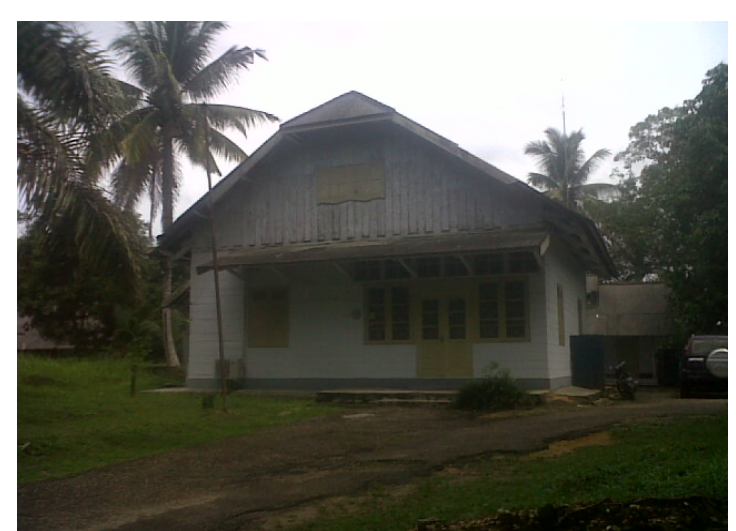

Gambar 2. Peninggalan Rumah Belanda di Bajubang.

\section{Rumah sakit peninggalan Belanda}

Rumah Sakit Pertamina di Bajubang (Gambar 4) merupakan salah satu peninggalan Belanda. Rumah sakit ini dibangun Belanda pada 1930. Rumah sakit tersebut menjadi salah satu rumah sakit terbesar bahkan menjadi rujukan masyarakat dari Jambi, Bungo, dan Muara Bulian. Pada masa pasakemerdekaan, rumah sakit ini dimiliki oleh Pertamina. Namun, setelah Pertamina tidak beroperasi di Bajubang, rumah sakit ini ditutup dan tidak digunakan.

Ciri arsitektur bangunan rumah sakit ini merupakan bangunan peninggalan Belanda (Gambar 3). Bangunan yang dibangun pada masa kolonial ini memiliki bentuk simetris, bertembok tebal dengan langit-langit yang tinggi. Bagian depan terdapat pilar-pilar dengan tata ruang terbuka, beratap perisai dengan beranda luas, pintu jendela berukuran besar, dan didominasi warna putih (Wawancara dengan Sukarman, 19 November 2018).

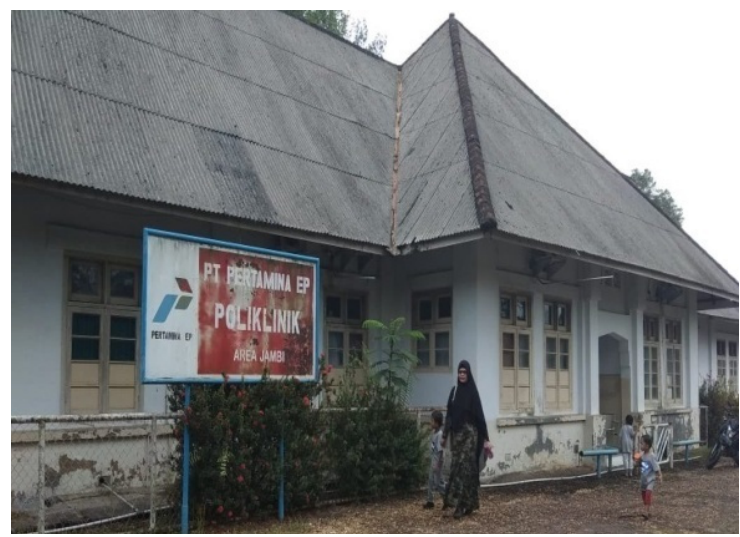

Gambar 3. Bekas Rumah Sakit Peninggalan Belanda di Bajubang.

\section{Lapangan golf}

Lapangan golf ini (Gambar 4) dibangun oleh Belanda ketika menduduki Bajubang sekitar 1930-an. Lapangan ini merupakan lapangan golf yang paling lengkap meskipun saat ini sudah banyak pohon kelapa sawit tumbuh tinggi menjulang. Banyak yang datang dari berbagai daerah untuk bermain golf di lapangan ini seperti dari Kota Jambi, Batang Hari dan Muara Bungo (Wawancara dengan Sukarman, 19 November 2018).

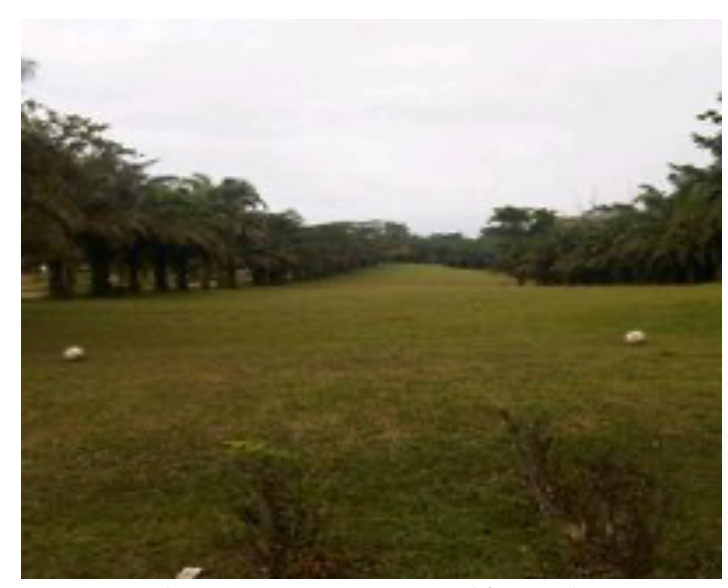

Gambar 4. Lapangan Golf Bajubang.

\section{Gua peninggalan Jepang}

Di Bajubang terdapat sebuah gua yang berlokasi di depan pintu masuk penjagaan security Pertamina. Gua itu dikenal warga sebagai goa yang dibangun pada masa pendudukan Jepang. Gua itu dibangun setelah berhasil mengusir para pengusaha Belanda dari Bajubang. Gua ini berfungsi sebagai tempat perlindungan (Wawancara dengan Sukarna, 20 November 2018). Akan tetapi, kondisi goa Jepang ini tidak bisa dimasuki lagi karena telah tertutup oleh tanah (tampak pada Gambar 5).

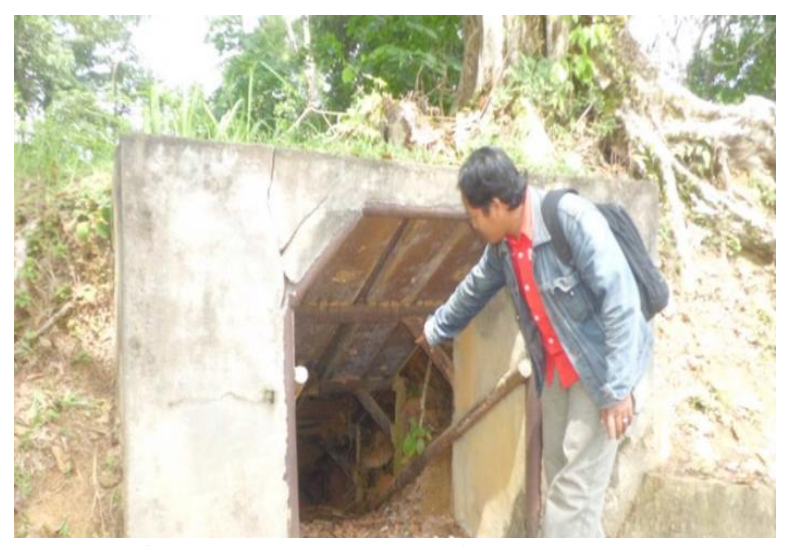

Gambar 5. Gua Peninggalan Masa Jepang. 


\section{Peralatan pumping}

Pumping (Gambar 6) ini digunakan untuk pengangkatan buatan (artificial lift) yang telah digunakan secara meluas pada lapangan minyak. Peralatan ini dapat memberikan gerakan turun naik (reciprocating motion) kepada rod string yang dihubungkan ke positive displacement pump dalam sumur minyak. Peralatan tersebut merupakan peralatan yang sudah dipakai sejak1950, akan tetapi setelah pertamina tidak mengunaakannya lagi peralatan Pertamina ini dibiarkan terlantar dan tidak dirawat (Wawancara dengan Sumbada, 18 November 2018).

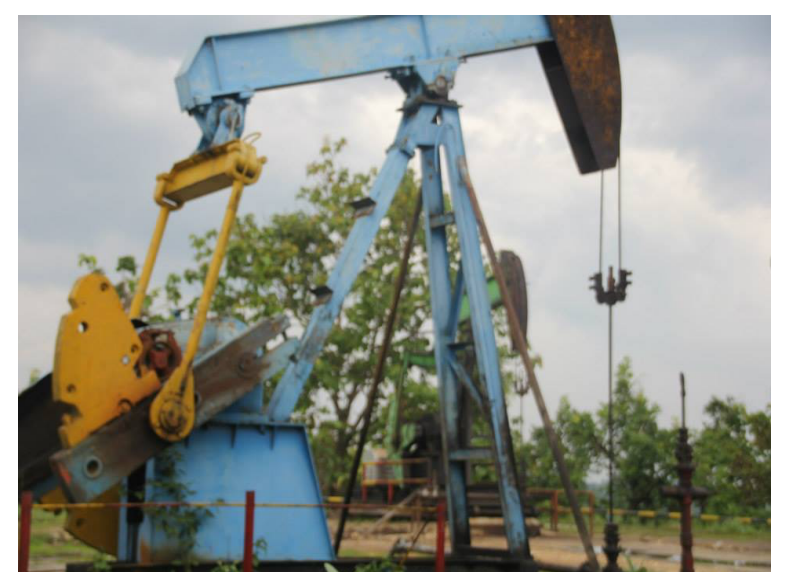

Gambar 6. Peninggalan Mesin Pumping Minyak di Bajubang.

\section{Bioskop Batanghari peninggalan NIAM}

Bajubang begitu makmur ketika berada di bawah NIAM pada dekade 1930an, hingga membangun gedung bioskop sebagai sarana hiburan. Bioskop Batanghari dibangun di kompleks pemukiman pegawai minyak Bajubang. Bioskop Batanghari memutar film tiga kali dalam sepekan. Film yang diputar dan paling sering ditonton adalah film India. Jadwal pemutaran film dimulai pada selepas maghrib. Masyarakat bisa berjam-jam nongkrong di Bioskop Batanghari itu. Untuk biaya masuk dikenakan tarif 5 perak/orang.

Bioskop Batanghari rupanya bukan satusatunya bioskop di kompleks Bajubang. Ada bioskop khusus untuk kalangan petinggi perusahaan, tempatnya di rumah dinas Pertamina. Orang-orang menyebutnya gedongan. ${ }^{7}$ Lokasinya berada di ujung kaki bukit, persis di depan lapangan golf. Gedongan memiliki alat pemutar film sebagaimana Bioskop Batanghari. Pada masa NIAM, bioskop gedongan merupakan tempat persamuhan orang-orang Belanda. Budaya itu terus berlangsung hingga era Pertamina (Wawancara dengan Mardan, 28 September 2019).

Masa itu masyarakat makmur sekali. Kendati sambil menonton film di bioskop para bos-bos Pertamina memborong semua dagangan para pedagang di kompleks Pertamina Bajubang. Para pegawai Pertamina juga kerap bersedekah untuk jemaah gereja yang sembahyang di kompleks Pertamina itu (Wawancara dengan Unita, 28 September 2019). Gambar 7 adalah bekas gedung bioskop di Bajubang.

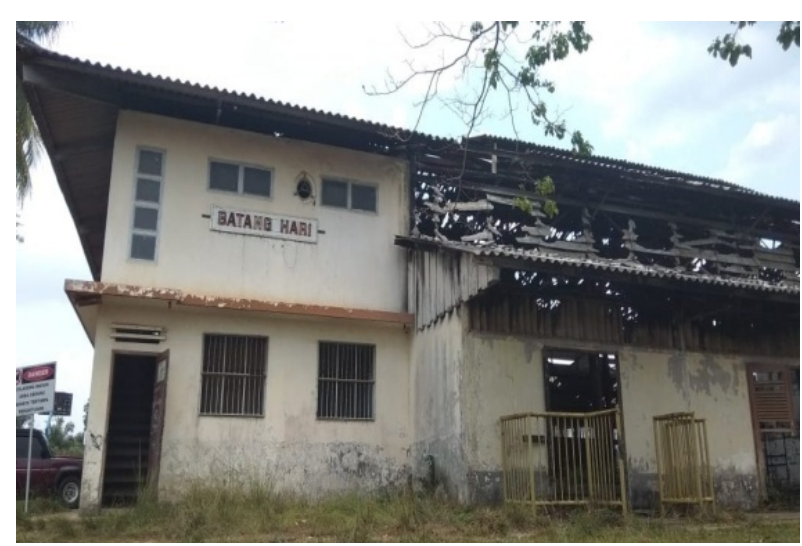

Gambar 7. Peninggalan Bioskop di Bajubang.

\section{Gereja Oikumene}

Puncak kejayaan Bajubang memang ditandai ketika NIAM sukses memproduksi minyak secara besar-besaran. Bajubang seketika menjadi kota modern. Bule-bule Belanda yang bekerja di NIAM ramai-ramai memboyong istrinya ke sana. Semua fasilitas mentereng dibangun mulai bioskop, lapangan golf, gedung pertemuan, rumah sakit, hingga gereja.

Berjarak 500 meter dari rumah sakit, berdiri tegak Gereja Oikumene. Agama Katolik berkembang di Jambi termasuk di Bajubang karena keadiran bos dan para pekerja NIAM dari Eropa. Remigius van Hoof pertama kali menjadi pembina umat katolik di Jambi, baru kemudian setelah itu digantikan oleh Henricus van Oort (https://www.parokiteresiajambi.com/sejarahgereja/, diakses 19 Juni 2021).

Jambi menjadi pos misi baru dalam Perfektur Apostik Bengkulu secara resmi pada 16 Januari 1935. Jumlah umat Katolik yang menjadi pastor berjumlah 177 orang, terdiri atas 127 orang Eropa serta 50 orang pribumi dan Tionghoa. Selama tahun 1936 tercatat dalam buku Baptis 
sebanyak 30 orang dipermandikan, selain 22 orang yang sudah dipermandikan sebelumnya. Setahun kemudian 13 orang dipermandikan, dan pada kurun waktu 1938-1939 bertambah 20 orang (https://www.parokiteresiajambi.com/sejarahgereja/, diakses 19 Juni 2021).

Gereja Oikumene (Gambar 8 dan Gambar 9) kemudian diresmikan pada 16 September 1973 oleh Kepala Lapangan Jambi S. Soekadis. Bangunan ini terlihat masih sangat kokoh. Kursikursi yang berasal dari kayu jati pilihan masih terlihat utuh dan bersih. Setiap Sabtu dilakukan kegiatan bersih-bersih dikarenakan pada hari Minggu akan dipakai untuk kegiatan peribadatan. Sampai sekarang gereja tersebut masih dipakai (Wawancara dengan Butet, 28 September 2019). Gereja tersebut dapat dilihat pada gambar berikut ini.

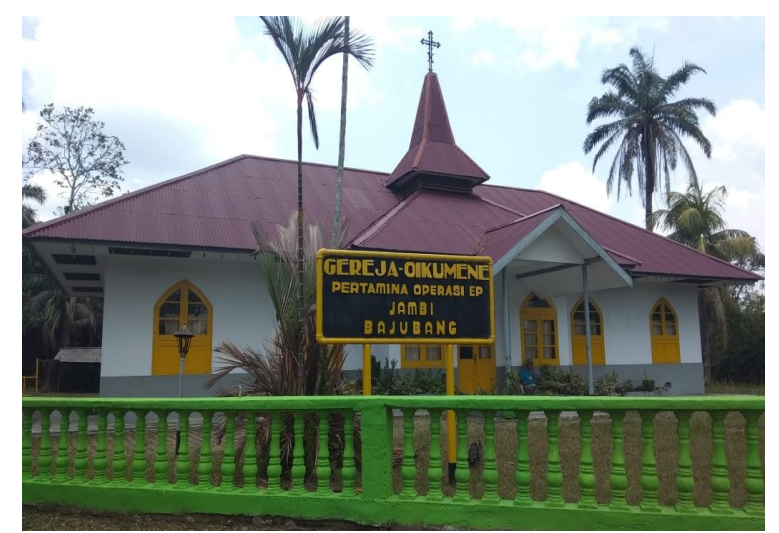

Gambar 8. Peninggalan Gereja Oikumene di Bajubang Masih Digunakan hingga Saat Ini.

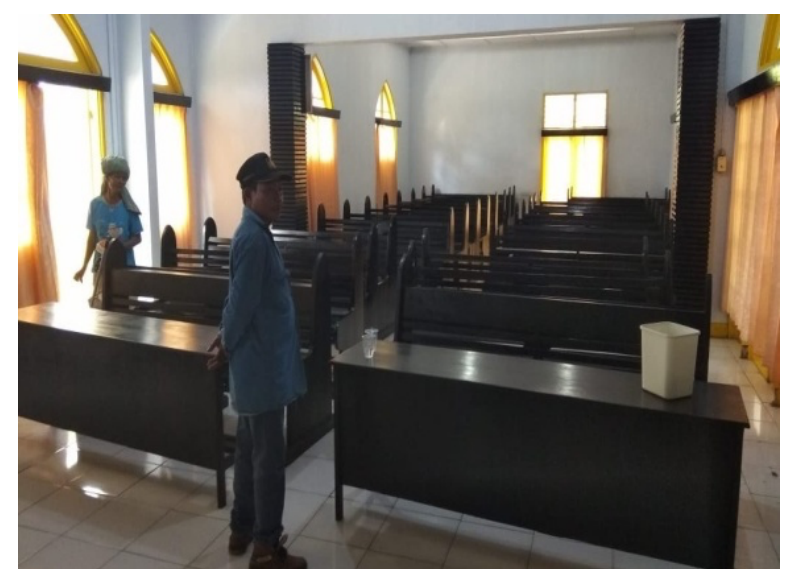

Gambar 9. Tampak Bagian Dalam Gereja

Oikumene.

\section{Pipa Penyaluran Minyak}

Salah satu peristiwa penting dalam sejarah kota minyak Bajubang adalah pembangunan jaringan pipa minyak menuju Plaju (Gambar10) sepanjang $270 \mathrm{~km}$ karena minyak Bajubang tidak pernah disuling di Jambi tetapi disuling di Plaju. Peresmian pembangunan jaringan pipa dihadiri Menteri Senior Belanda yaitu Mr. T. J. Verschuur yang menandatangani prasasti pembangunan pada 15 November 1935. Investasi pembangunan jaringan pipa ini memakan dana sekitar 3,5 juta Gulden (De Locomotive, 09 Juli 1938).

Pembangunan jaringan pipa ini mengalami tantangan luar biasa karena menembus hutan, sungai, dan kondisi cuaca yang tidak menentu. Pipa-pipa minyak diletakkan di sepanjang jalan dengan Panjang $109 \mathrm{~km}$. Jumlah pipa yang digunakan 23.736 pipa yang ukuran setiap pipanya 11,3 meter. Pipa disambungkan dengan cara dilas (De Tijd, 17 November 1935).

Plaju sudah terlebih dahulu lebih maju daripada Jambi dalam perminyakan. Kilang di Plaju dibangun pada 1900. Pada 1928, Thomas Karsten telah membuat peta perencanaan yang menjadikan kilang minyak Plaju sebagai kawasan industry Palembang (Liana, 2019:56). Bataafsche Petroleoum Maatschappij (BPM) sebagai pengelola minyak di Plaju merupakan pemegang saham 50\% di NIAM yang mengelola minyak di Jami termasuk Bajubang. Cukup masuk akal kalau minyak dari Bajubang disalurkan melalui jaringan pipa untuk diolah di Plaju.

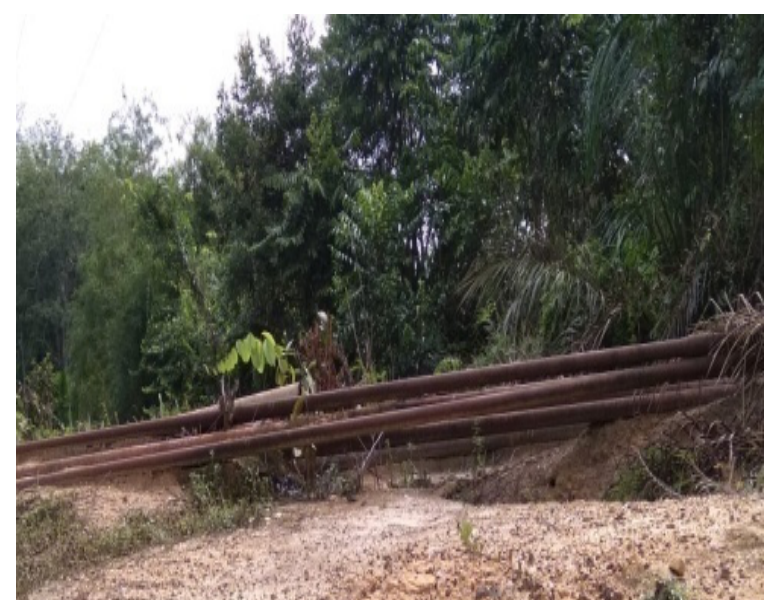

Gambar 10. Pipa Penyaluran Minyak.

\section{Sekolah Yayasan Kesejahteraan Pegawai Pertamina (YKPP)}

Pertamina Bajubang juga mendirikan yayasan pendidikan dengan fasilitas paling lengkap ketika masa kedigdayaannya. Semua jenjang sekolah mulai dari tingkat dasar hingga menengah 
dibangun di bawah naungan YKPP. Semua sekolah milik Pertamina itu kini sudah diambil alih pemerintah dan beralih status menjadi sekolah negeri (Wawancara dengan Mardan, 28 September 2019).

YKPP resmi dibentuk pada 1952 yang memiliki tujuan untuk mencetak generasi penerus bangsa yang berkualitas serta berpendidikan yang baik. YKPP membuka dan mendirikan institusi pendidikan pendidikan formal pertama yaitu SD Pertamina. Sekolah ini akhirnya berubah nama menjadi SD Pertamina Nomor 04 berdasarkan SK Depdikbud Provinsi Jambi No.5236/I 10.12/b/Ib84 sekaligus juga menjadi dasar dari izin pendirian bangunan sekolah.

Institusi pendidikan yang kedua YKPP yaitu SMP Tanah Minyak yang berdiri pada 1 Maret 1971. Sekolah ini didirikan dengan tujuan untuk meringankan beban biaya sekolah para orang tua peserta didik khususnya pegawai Pertamina. SMP Tanah Minyak ini secara resmi dibuka tanggal 05 Maret 1971 berdasar pada SK Perwakilan Depdikbud RI Kantor Pembina PMUP Provinsi tanggal 15 Desember 1971 No. 1772/U-6/PUMP$\mathrm{XII} / 71$.

SMP Tanah Minyak ini dalam perjalanannya telah berganti-ganti nama, mulai dari SMP Tanah Minyak pada 1971-1974 menjadi SMP Yayasan Karya Baru tahun 1974-1978, berubah lagi menjadi SMP Yaktapena tahun 1987, dan baru menjadi SMP YKPP tanggal 23 Maret 1987 sampai sekarang berdasarkan SK Kepala Kantor Wilayah Depdikbud Provinsi Jambi tanggal 10 Mei No. 1509/I 10,2.Ib/1982 tentang pembukaan sekolah dengan status terdaftar.

Sekolah Dasar Pertamina memperoleh akreditasi dengan peringkat $\mathrm{B}$ ditunjukkan dengan perolehan Sertifikat Akreditasi Sekolah No. 006. Sementara SMP sudah memperoleh status terdaftar di awal pembukaan berdasar SK Kepala Kantor Wilayah Depdikbud Provinsi Jambi tanggal 10 Mei No. 1509/I 10,2.Ib/1982 dan selanjutnya terus mendapat status akreditasi dengan peringkat A yang ditunjukkan melalui Sertifikat Akreditasi SMP/Madrasah Tsanawiyah YKPP Jambi No. 450/BAP-SM/X/2015). Bangunan sekolah tersebut dapat dilihat pada Gambar 11.

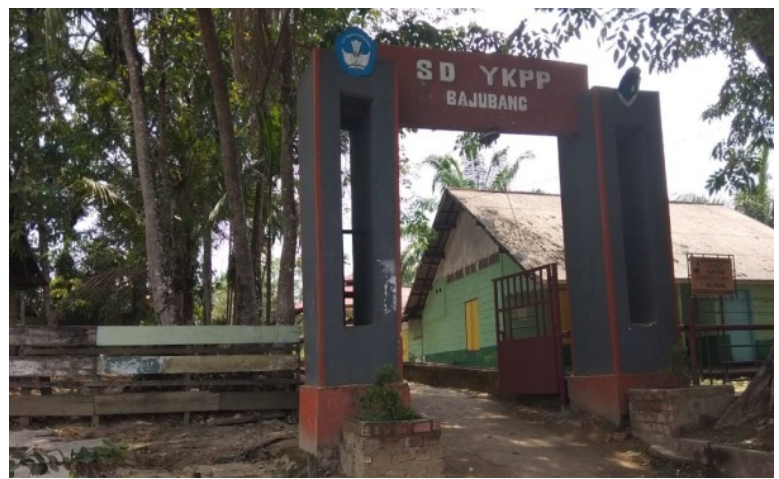

Gambar 11. Peninggalan Sekolah YKPP di Bajubang.

\section{Meriam Belanda}

Jejak Belanda yang masih tersimpan di kompleks Bajubang adalah sebuah meriam. Meriam tersebut masih utuh hingga kini dan sudah tidak digunakan lagi. Kendati demikian, ketika sore hari banyak muda-mudi ramai berswafoto (Wawancara dengan Mardan, 28 September 2019). Adapun meriam tersebut seperti yang tampak pada Gambar 12.

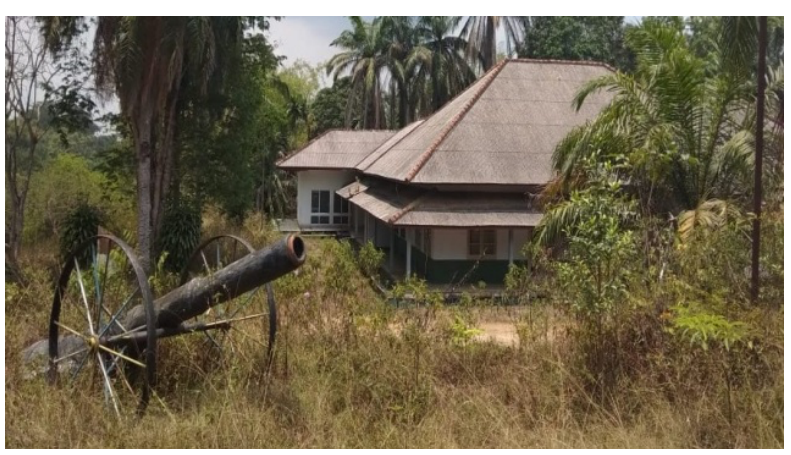

Gambar 12. Meriam Peninggalan Belanda di Bajubang.

\section{Kilang minyak peninggalan Permiri}

Permiri sebagai cikal bakal Pertamina yang lahir pada dekade 1946 mencatatkan kegemilangan setelah berhasil memproduksi avian turbin alias avtur, yaitu bahan bakar minyak untuk pesawat terbang. Kapasitas produksi oleh kilang minyak tersebut mencapai 40 ton minyak tanah dan 20 ton solar per hari. Uji coba avtur pertama kali dilakukan pada Maret 1948. Saat itu, sebuah pesawat Avro Anson $^{8}$ datang ke Jambi. Benar saja, bensin udara itu siap dipakai, mutu avtur yang telah disempurnakan OMU-2 ternyata memenuhi standar dan pesawat berhasil terbang tinggi tanpa hambatan. 
Sejak itu, avtur produksi Jambi terus dipakai oleh jawatan minyak seantero nusantara. Keberhasilan ini menjadikan Jambi sebagai pusat pengisian bahan bakar pesawat terbang di masa revolusi. Berbagai pesawat yang ditumpangi para pemimpin Republik di masa revolusi singgah di Jambi untuk mengisi bahan bakar.

Jejak kilang minyak (Gambar 13) tersebut masih utuh dan peninggalan itu masih berdiri tegak kokoh diantara semak belukar. Sebuah prasasti tertulis di bawah kilang menyebutkan kilang minyak avigas itu didirikan pada tahun 1946 oleh Permiri. Kilang tersebut diresmikan pada 1966 oleh Presiden Soeharto sebagai monumen perjuangan atas hasil produksi avigas (Wawancara dengan Gondo Irawan, 30 September 2019).

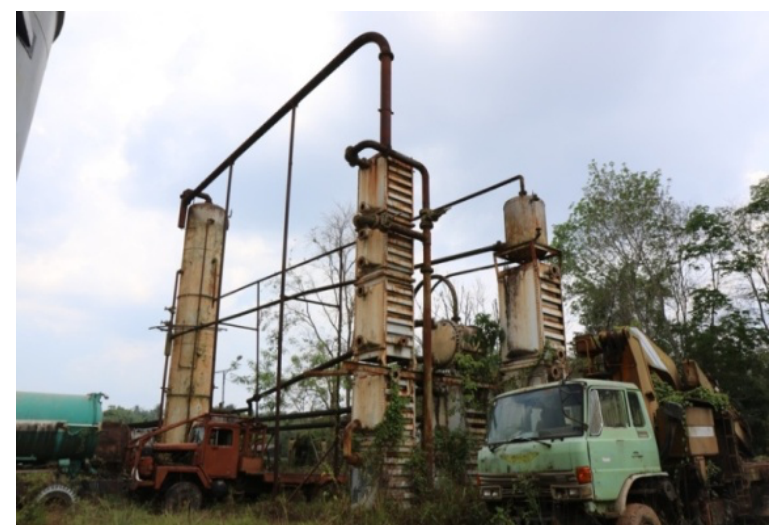

Gambar 13. Kilang Minyak yang Dibangun pada Era Permiri.

\section{Simpulan}

Eksplorasi minyak di Jambi tidak terlepas dari tujuan Belanda untuk memperluas pengaruhnya di luar Jawa. Belanda melalui perusahaan minyaknya yaitu NIAM (Nederlandsch-Indische Aardolie Maatschappij) sudah mengincar minyak Jambi sejak lama dan menemukan serta melakukan pengeboran pertama di daerah Bungin Batu (Bajubang Laut) pada tahun 1916.

Bajubang merupakan daerah penghasil minyak tertua dan dikenal sebagai kota minyak terbesar di Provinsi Jambi. Belanda mengincar Bajubang karena mempunyai objek vital dalam hal persediaan bahan bakar pesawat dan pasukan tentara. Oleh sebab itu, sempat terjadi konflik sengit sampai dengan tahun 1920 antara Belanda (NIAM) dan Amerika Serikat (Asam Merah) yang pada akhirnya kota minyak Bajubang disetujui untuk dikelola oleh Belanda (NIAM) melalui sistem kontrak.

Terdapat tiga pengelola minyak di Bajubang. Pada 1920-1942 minyak dikelola oleh Belanda melalui perusahaannya yaitu NIAM. Kemudian pada masa pendudukan Jepang 1942, pengelolaan minyak di Bajubang diambil oleh Jepang. Jepang mendirikan tempat latihan tenaga kerja yakni pendidikan minyak di Bajubang pada 1944. Jepang juga meninggalkan bukti kekuasaannya selama di Bajubang dengan membangun gua yang difungsikan sebagai basis pertahanan.

Usai Jepang hengkang karena kekalahan perang, pejuang Indonesia di bawah Permiri mengelola minyak Bajubang. Pada masa ini, minyak Jambi termasuk minyak dari Bajubang berperan sangat penting sebagai bahan bakar pesawat udara, pembuatan berbagai macam bentuk senjata, serta pembuatan BBM yang digunakan sebagai pertahanan untuk memblokade serangan musuh saat Agresi Militer Belanda I dan II.

Peningalan-peninggalan yang ada di Bajubang cukup komplet. Beberapa fasilitas seperti lapangan golf, perlengkapan tambang minyak, bangunan rumah, dan rumah sakit di Bajubang saat ini menjadi saksi bisu dari dinamika sejarah di Bajubang.

\section{Catatan}

${ }^{1}$ NIAM adalah perusahaan eksplorasi minyak yang dibentuk oleh pemerintah Belanda untuk menandingi perusahaan asal Amerika yang bernama SVPM. Setelah perang dunia II NIAM berubah menjadi PT. Permindo dan pada tahun 1968 menjadi PT. Pertamina. Lihat Perpu Nomor 46 tahun 1960.

${ }^{2}$ Hidrokarbon adalah senyawa yang terkandung dalam minyak bumi. Minyak bumi terbentuk akibat pelapukan sisa-sisa atau bangkai hewan dan tumbuhan renik serta lapisan-lapisan lumpur yang terkubur dalam jangka waktu jutaan tahun lamanya. Komposisi minyak bumi terdiri dari hidrokarbon alkana, sikloalkana dan senyawa aromatik. Susunan hidrokarbon dalam minyak bumi berbeda-beda tergantung dari umur dan suhu pembentukan zat tersebut. Tambang minyak bumi di Indonesia banyak mengandung senyawa hidrokarbon siklik (sikloalkana maupun aromatik) dengan kadar belerang rendah. 
${ }^{3}$ Perusahaan asing Amerika tersebut bernama SVPM dan pada 1920 masuk dua perusahaan Amerika baru yaitu Standard Oil of California dan Texaco.

${ }^{4}$ Permiri merupakan sebuah perusahaan yang didirikan sebagai tindak lanjut pengambilalihan semua tambang dan kilang minyak yang beroperasi di Sumatera Selatan dan Jambi oleh pejuang kemerdekaan Republik Indonesia saat NIAM yang didirikan Belanda jatuh ke tangan Jepang dan Pemerintahan Jepang menyerah pada 1945. Penyerahan dilaksanakan di Bajubang oleh oleh Matsuda Butai. Lebih lanjut dapat dibaca dalam buku: Peranan Permiri Dalam Perjuangan Mempertahankan Kemerdekaan RI di Jambi 19451949. Dinas Kebudayaan dan Pariwisata Provinsi Jambi.

${ }^{5}$ Neetherlands Indies Civil Administration (NICA) adalah pemerintahan sipil Hindia Belanda yang bertugas mengembalikan hukum pemerintahan Belanda selepas pendudukan Jepang di Indonesia yakni setelah Perang Dunia II atau Perang Pasifik.

${ }^{6}$ Pumping adalah pompa angguk yang digunakan apabila sumur minyak sudah tidak dapat lagi mengangkat minyak dari dasar sumur ke atas permukaan secara sembur alam sehingga perlu dilakukan pengangkatan buatan yang menggunakan tenaga pengangkatan buatan (artificial lift methods).

${ }^{7}$ Gedongan adalah bangunan rumah atau tempat tinggal yang bagus serta dapat diartikan pula orang kaya.

${ }^{8}$ Avron Anson adalah pesawat keluaran Inggris yang merupakan pesawat ketiga yang dimiliki oleh pemerintah Republik Indonesia dan dibeli pada awal Desember 1947. Pesawat tersebut dibeli dari sumbangan masyarakat Sumatera Barat berupa emas berkisar $14 \mathrm{Kg}$ dari Paul H. Keegan warga Negara Australia dan mantan penerbang Angkatan Udara Kerajaan Inggris. Pesawat tersebut didatangkan langsung oleh Keegan ke lapangan udara Gadut, Bukittinggi.

${ }^{9}$ Seulawah adalah pesawat angkut buatan Amerika pertama berjenis Dakota yang dimiliki oleh pemerintah Republik Indonesia. Pesawat tersebut dibeli berasal dari sumbangan rakyat Aceh yang berhasil mengumpulkan dana setara dengan $20 \mathrm{Kg}$ emas. Seulawah sendiri artinya adalah "gunung emas" yang kemudian pesawat tersebut diberi nama Dakota RI-001 Seulawah.

\section{Referensi}

Allain, Remy (2004). Morphologie Urbaine: Geographie, Amenagement et architecture de la ville. Paris: Armand Colin.

Black, Jeremy, MacRaild, D. M. (2007). Studying History. New York: Palgrave Macmillan.

Dharmasaputra, Metta (2015). Wajah Baru Industri Migas Indonesia. Jakarta: Katadata Indonesia.

De Locomotive, 09 Juli 1938.

De Sumatra Post, 28 Oktober 1926.

De Tijd, 17 November 1935.

Dinas Kebudayaan dan Pariwisata Provinsi Jambi (1990). Peranan Permiri Dalam Perjuangan Mempertahankan Kemerdekaan RI Di Jambi 1945-1949. Jambi: Museum Perjuangan Rakyat Jambi.

Hasibuan, R. R. (2017). Pertamina EP Asset 1. Jambi.

Het Nieuws Van den Hag, 13 September 1938. Jaarverslag over 1940 van de N. V. NederlandsenIndische Aardolie Maatschappij te 'sGravenhagel, hlm. 2.

Kanumoyoso, Bondan (2018). Pengetahuan dan Kuasa Kolonial : Jambi Abad 19 dalam Sejarah Indonesia. Makalah dalam diskusi sejarah "Midden Sumatra Expeditie 18771879: Eksplorasi Sejarah Jambi yang digelar kajanglako.com, 04 Oktober 2018.

Kuncoro, M. (2003). Ekonomi Pembangunan Teori, Masalah dan Kebijaksanaan. UPP AMP YKPN: Yogyakarta.

Liana, Ida T. (2019). Palembang dan Plaju: Modernitas dan Dekolonisasi di Perkotaan Sumatra Selatan Abad Ke 20. Yogyakarta: Ombak.

Moor, J. M. De (1923). De Gemengde Onderneming in Hare Economische Beteekenis. Disertasi. Universitas Amsterdam.

Nieuwe Leidsche Courant, 10 Januari 1935. Ooi, Jin Bee (1982). The Petroleum Resources of Indonesia. Kuala Lumpur: Oxford University Press. 
Poesponegoro, Marwati Djoened, Notosusanto, N. (2010a). Sejarah Nasional Indonesia II. Jakarta: Balai Pustaka.

Ricklefs, M. C. (2001). A History of Modern Indonesia Since 1200. California: Stanford University Press.

Rohati, S. (2017). Sejarah Bajubang Dulu, Kini dan Mendatang. Bajubang.

Scholten, Elsbeth Loscher (2008). Kesultanan Sumatra dan Negara Kolonial: Hubungan Jambi-Batavia (1830-1907) dan Bangkitnya Imperialisme Belanda. Jakarta: Bana KITLV.

Setianto, Heri dan Murjainah (2019). Hubungan Pola Persebaran Permukiman dengan Kualitas Air Tanah di Kecamatan Plaju Kota Palembang. Jurnal Geografi 16(1), 60-71.

Sumalyo, Yulianto (1997). Arsitektur Modern Akhir Abad XIX dan XX. Yogyakarta: Gajah Mada University Press.

Susanto, Nugroho Nur (2011). Kehadiran Belanda dan Tata Kota Balikpapan. Jurnal Naditira Widya 5 (1), 46-59.

The New York Times, 10 Juli 1920.

Tim Penyusun Kamus Pusat Bahasa (2007). Kamus Besar Bahasa Indonesia. Jakarta: Balai Pustaka.

Yunus, Hadi Sabari (2006). Struktur Tata Ruang Kota. Yogyakarta: Pustaka Belajar.

https://www.parokiteresiajambi.com/sejarahgereja/, diakses 19 Juni 2021.

\section{Daftar Informan}

Wawancara dengan Andrew dan Pjs Asset 1 Legal dan Relation Manager, 30 September 2019.

Wawancara dengan Butet, 28 September 2019.

Wawancara dengan Gondo Irawan, 30 September 2019.

Wawancara dengan Mardan, 28 September 2019.

Wawancara dengan Rusman, 09 Juli 2018.

Wawancara dengan Sukarman, 19 November 2018.

Wawancara dengan Sukarna, 20 November 2018.

Wawancara dengan Sumbada, 18 November 2018.

Wawancara dengan Suwastio, 10 November 2018.

Wawancara dengan Unita, 28 September 2019.

Wawancara dengan Zainal Abidin, 9 Juli 2018. 